\title{
Pharmacokinetics of intravenous and
} intramuscular danofloxacin in red-eared slider turtles (Trachemys scripta elegans)

\author{
Orhan CORUM ${ }^{1) *}$, Duygu Durna CORUM ${ }^{1)}$, Feray ALTAN ${ }^{2)}$, Ayse ER ${ }^{3)}$, Gul CETIN ${ }^{4)}$ \\ and Kamil UNEY3) \\ ${ }^{1)}$ Department of Pharmacology and Toxicology, Faculty of Veterinary Medicine, University of Kastamonu, \\ Kastamonu, 37200, Turkey \\ 2)Department of Pharmacology and Toxicology, Faculty of Veterinary Medicine, University of Dicle, Diyarbakir, \\ 21280, Turkey \\ 3) Department of Pharmacology and Toxicology, Faculty of Veterinary Medicine, University of Selcuk, Konya, \\ 42031, Turkey \\ ${ }^{4)}$ Department of Pharmacology, Faculty of Pharmacy, University of Erzincan, Erzincan, 25100, Turkey
}

J. Vet. Med. Sci.

81(5): 753-757, 2019

doi: 10.1292/jvms.18-0609

Received: 14 October 2018 Accepted: 28 February 2019 Published online in J-STAGE: 11 March 2019

\begin{abstract}
This study aimed to investigate the pharmacokinetics of danofloxacin in red-eared slider turtle (Trachemys scripta elegans) following a single intravenous (IV) and intramuscular (IM) administrations of $6 \mathrm{mg} / \mathrm{kg}$, using a two-way crossover study with 30-day washout period. Eight clinically healthy red-eared slider turtle weighing 410-600 g (mean $490 \mathrm{~g}$ ) were used for the study. Danofloxacin concentrations were measured using the reversed-phase high-performance liquid chromatography. The plasma concentration-time data were evaluated by a non-compartmental method. After IV administration, the elimination half-life $\left(t_{1 / 2 K_{z}}\right)$, mean residence time $\left(\mathrm{MRT}_{0-\infty}\right)$, area under the concentration-time curve $\left(A \cup C_{0-\infty}\right)$, volume of distribution at steady state and total body clearance in plasma were $24.17 \mathrm{hr}, 30.64 \mathrm{hr}, 143.31 \mathrm{hr} \cdot \mu \mathrm{g} / \mathrm{ml}, 1.29 \mathrm{l} / \mathrm{kg}$ and $0.04 \mathrm{l} / \mathrm{hr} / \mathrm{kg}$, respectively. Following IM administration, $t_{1 / 2, z}, M T_{0-\infty}, A U C_{0-\infty}$, peak concentration $\left(C_{\text {max }}\right)$, time to reach $C_{\max }$ and bioavailability in plasma were $32.00 \mathrm{hr}, 41.15 \mathrm{hr}, 198.23 \mathrm{hr} \cdot \mu \mathrm{g} / \mathrm{ml}, 8.75 \mu \mathrm{g} / \mathrm{ml}$, $1.5 \mathrm{hr}$ and $139.89 \%$, respectively. Danofloxacin has clinically superior pharmacokinetic properties, including the complete IM absorption, slow elimination and wide volume of distribution in redeared slider turtles. However, further pharmacokinetics/pharmacodynamics studies are necessary for the treatment of diseases caused by susceptible bacteria with known minimum inhibitory concentration values in red-eared slider turtles.
\end{abstract}

KEY WORDS: bioavailability, danofloxacin, pharmacokinetics, red-eared slider turtles

Currently, red-eared slider turtles (Trachemys scripta elegans) are one of the most preferred pets. These were first used as pets in the 1950s, and their exportation had considerably increased because they became popular in pet and food trade [22]. The reasons for the increased popularity of red-eared slider turtles as pets are their characteristics such as small size, long lifetime, low care costs, and their ability to easily adapt to environmental conditions [5]. However, the widespread use of red-eared slider turtles has led to some undesired consequences. Conditions such as deterioration of natural environment, rise of dense environments, reduction of natural habitat of turtles, and stress have weakened their immune system and rendered them vulnerable to infections $[3,24]$. Because red-eared slider turtles were fed at farms to meet the increased demand in pet and food industries, the rate of bacterial diseases in these turtles increased. Salmonella spp., Mycoplasma spp., Pasteurella spp., and Aeromonas spp. are among the primary factors causing bacterial diseases in red-eared slider turtles $[6,14]$. These bacteria cause several diseases such as septicemia, respiratory tract disease, abscesses, conjunctivitis, stomatitis, shell infections, osteomyelitis, coelomitis, and skin ulcers in turtles $[6,14,21]$. In addition, red-eared slider turtles are carriers of zoonotic Salmonella spp. These bacteria cause enteritis and septicemia in turtles as well as in humans [4].

Fluoroquinolones are one of the most commonly used antibiotic groups for the treatment of bacterial infections in turtles [21]. The reasons for preferring fluoroquinolones are their low binding activity to plasma proteins, wide distribution volume, and good tissue penetration [30]. Danofloxacin, which acts by inhibiting the DNA gyrase enzyme of the bacteria, is a fluoroquinolone-group antibiotic approved for use in cattle, swine, and chicken $[7,15]$. Danofloxacin is a broad-spectrum antibiotic covering gramnegative and gram-positive bacteria and Mycoplasma spp. [20, 26]. Danofloxacin is recommended for use in Caretta caretta for 
various infections [19] and in tortoises for mycoplasmosis [11]. Although enrofloxacin is used in turtles for many diseases such as conjunctivitis [13] and lower respiratory diseases [11], it may cause undesired side effects such as skin irritation, hyper salivation, and anorexia [6]. Danofloxacin exhibited long elimination half-life, wide distribution volume, and high bioavailability in $C$. caretta with no side effects [19]. It can also be preferred in bacterial diseases of red-eared slider turtles for its pharmacokinetic and pharmacodynamic properties. Although danofloxacin pharmacokinetics had been assessed for ectotherm animals species of C. caretta [19] and some fish species [18,27], there are no studies in red-eared slider turtles. This study aimed to determine the pharmacokinetics and bioavailability of danofloxacin following intravenous (IV) and intramuscular (IM) administration at $6 \mathrm{mg} / \mathrm{kg}$ dose in red-eared slider turtles.

\section{MATERIALS AND METHODS}

\section{Animals}

All experiments on turtles were approved by Selcuk University, Faculty of Veterinary Medicine, Ethics Committee prior to the study. Eight healthy red-eared slider turtles weighing 410-600 g (mean, $490 \mathrm{~g}$ ) that had not received any medication in the previous 2 months were used in the study. Turtles were procured from a local pet shop (Konya/Turkey) and were maintained in $450 l$ aquariums housing four turtles each. Water temperature was maintained at $22-24^{\circ} \mathrm{C}$ using aquarium heater. A dry basking area was heated to $30^{\circ} \mathrm{C}$ by using an infrared lamp. Aquarium system contained a custom-built mechanical and biological filtration. Turtles were fed with commercial feed daily (Sera Reptil Raffy P, GmbH, Heinsberg, Germany). The study was conducted following a 2-week acclimatization period after turtles were transferred to the aquariums. At the beginning of and during the study, the health status of the turtles was evaluated through physical examination, feed consumption, and plasma biochemical parameters.

\section{Experimental design, drug administration, and blood sampling}

The study was conducted in a two-way crossover pharmacokinetic design with a 30-day drug washout interval between administrations $(4 \times 4)$. Danofloxacin was administered to the turtles at $6 \mathrm{mg} / \mathrm{kg} \mathrm{IV}$ and IM doses. The jugular vein was used for IV administration, and the deltoid muscle was used for IM administration. For IV and IM drug administration to the turtles, the parenteral formulation of danofloxacin mesylate (Advocin, $25 \mathrm{mg} / \mathrm{m} l$ injectable solution, Zoetis, Turkey) was diluted to $10 \mathrm{mg} / \mathrm{m} l$ using sterile water for injection. Blood samples of approximately $0.17 \mathrm{~m} l$ were collected from dorsal venous sinus at $0,0.5,1,1.5$, $3,6,9,12,18,24,36,48,72,96,120$, and $144 \mathrm{hr}$ by using an insulin injector previously washed with $0.05 \mathrm{ml}$ heparin sodium. Subsequently, the collected blood samples were centrifuged at $4,000 \mathrm{~g}$ for $10 \mathrm{~min}$ and the obtained plasma samples were stored at $-70^{\circ} \mathrm{C}$ until further analysis.

\section{Drug analysis}

Danofloxacin concentration in turtle plasma was analyzed using a high-performance liquid chromatography (HPLC)-UV system (Shimadzu, Tokyo, Japan). HPLC system contained pump (LC-20AT), degasser (DGU-14A), auto-sampler (SIL-20A), and column oven (CTO-10A). Danofloxacin analysis was conducted by modifying the pre-specified methods [23, 25]. For analysis, turtle plasma samples at $-70^{\circ} \mathrm{C}$ were thawed to room temperature and vortexed before use. Further, $150 \mu l$ acetonitrile was added to 75 $\mu l$ plasma and vortexed for $30 \mathrm{sec}$. Then, $100 \mu l$ of the clean supernatant was transferred to HPLC vial after centrifuging at 10,000 $g$ for $10 \mathrm{~min}$, and $30 \mu \mathrm{l}$ of the supernatant was injected in the HPLC-UV system. The UV-visible (SPD-10A) detector was set at 280 wavelength. Gemini ${ }^{\mathrm{TM}} \mathrm{C} 18$ column $(250 \times 4.6 \mathrm{~mm}$; internal diameter, $5 \mu \mathrm{m}$; Phenomenex, Torrance, CA $)$ was used for the separation of danofloxacin. Further, $18 \%$ mobile phase from A (acetonitrile) and $82 \%$ mobile phase from B $(0.4 \%$ triethylamine + $0.4 \%$ orthophosphoric acid) were pumped to the HPLC system using a pump containing a low-performance gradient system. The flow rate was $1 \mathrm{ml} / \mathrm{min}$. The column temperature was kept at $40^{\circ} \mathrm{C}$, whereas the auto-sampler was kept at room temperature.

The method was validated in plasma for 6 days in terms of HPLC system selectivity, linearity, sensitivity, recovery, accuracy and precision. Danofloxacin pure substance ( $\geq 98 \%$, Sigma-Aldrich, St. Louis, MO., U.S.A.) was used to prepare working standards $(0.04-20 \mu \mathrm{g} / \mathrm{ml})$ in water. The peak of danofloxacin did not interfere with endogenous substances, showing the selectivity of method. Calibration standards were prepared from a pool of turtle plasma spiked with eight concentrations of danofloxacin between 0.04 and $20 \mu \mathrm{g} / \mathrm{ml}$. For calibration standards analyzed in six replicate, the correlation coefficients were found to be $>0.9995$ indicating functional linear relationship between the concentration of analyte and the area under the peak. The limit of detection for danofloxacin was $0.02 \mu \mathrm{g} / \mathrm{ml}$, which was the lowest concentration of danofloxacin resulting in a signal to noise ratio of 3. The limit of quantification was $0.04 \mu \mathrm{g} / \mathrm{ml}$, which was the lowest concentration quantified with a coefficient of variation (CV) of $<20 \%$. The recovery, precision and accuracy of assay were determined using quality control samples, which were prepared in six replicates at three concentration levels $(0.1,1$, and $10 \mu \mathrm{g} / \mathrm{m} l)$ and analyzed using the extraction procedure outlined above. The recovery of danofloxacin from plasma ranged from 94 to $103 \%$. Intra-day and inter-day CVs were $<5.3$ and $6.8 \%$, respectively. Intra- and inter-batch accuracy, which were determined by calculating the $\%$ bias [Bias $(\%)=100 \times($ calculated concentrationtheoretical concentration)/ theoretical concentration] were within acceptable limits of $\pm 15 \%$ at all concentration levels.

\section{Pharmacokinetic calculations}

Pharmacokinetic parameters were determined for each turtle following IV and IM administrations. Parameter estimates were calculated using WinNonlin 6.1.0.173 computer software (Pharsight Corporation, Scientific Consulting Inc., North Carolina, U.S.A.). In the study, non-compartmental pharmacokinetic parameters including the area under the plasma concentration-versus 


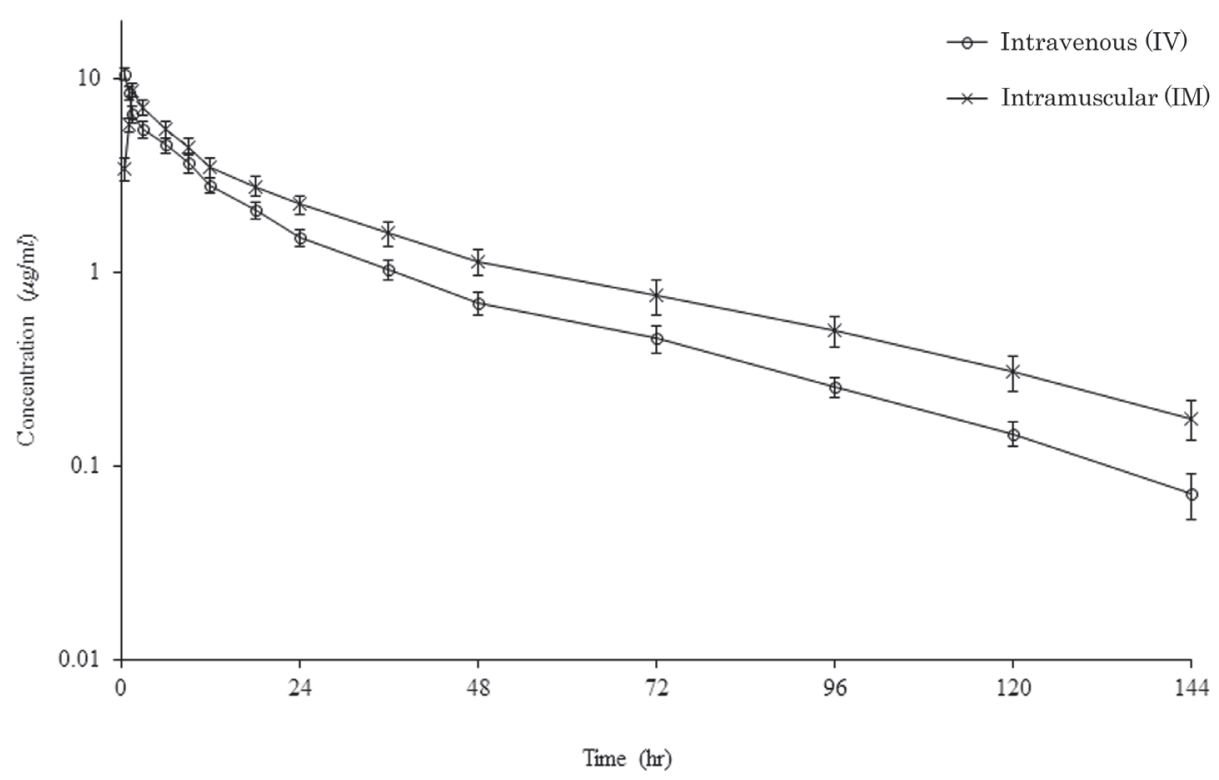

Fig. 1. Mean \pm SD semi-logarithmic plasma concentration-time curves of danofloxacin following intravenous and intramuscular administrations at the dose of $6 \mathrm{mg} / \mathrm{kg}$ in red-eared slider turtles $(\mathrm{n}=8)$.

time curve (AUC), terminal elimination half-life $\left(\mathrm{t}_{1 / 2 \mathrm{Z}}\right)$, mean residence time (MRT), mean absorption time (MAT), volume of distribution at steady state $\left(\mathrm{V}_{\mathrm{dss}}\right)$, and total clearance $\left(\mathrm{Cl}_{\mathrm{T}}\right)$ were measured. The initial concentration $\left(\mathrm{C}_{0}\right)$, peak plasma concentration $\left(\mathrm{C}_{\max }\right)$, and time to reach $\mathrm{C}_{\max }\left(\mathrm{T}_{\max }\right)$ were determined by direct observation of plasma concentration-time plot of the animals. The $\mathrm{t}_{1 / 2 \mathrm{Kz}}$ was calculated by $\ln 2 / \mathrm{kel}$. MAT was calculated as MAT $=\mathrm{MRT}_{\mathrm{IM}}-\mathrm{MRT}_{\mathrm{IV}}$. AUC was estimated by the linear/log method. Bioavailability (F) was calculated by using AUC values following IV and IM administration $\left(\mathrm{F}=\mathrm{AUC} \mathrm{C}_{0-\infty(\mathrm{IM})} / \mathrm{AUC} \mathrm{C}_{0-\infty(\mathrm{IV})}\right.$ $\times 100)$.

\section{Statistical analysis}

Statistical analysis were conducted using SPSS 22.0 commercial software (IBM Corp, Armonk, NY, U.S.A.). All values were presented as mean $\pm \mathrm{SD}$. Paired $t$-test was used for the evaluation of differences between pharmacokinetic parameters based on the route of administration. Harmonic mean was calculated for $\mathrm{t}_{1 / 2 \mathrm{Kz}}$ and MRT values, which were compared with Wilcoxon's Rank Sum test. $P<0.05$ was considered to be statistically significant.

\section{RESULTS}

Following IV and IM administration of danofloxacin at a dose of $6 \mathrm{mg} / \mathrm{kg}$ in red-eared slider turtles, no adverse drug effects were observed either locally or systematically. The semi-logarithmic plasma concentration-time curves and pharmacokinetic parameters following IV and IM administration of danofloxacin at a dose of $6 \mathrm{mg} / \mathrm{kg}$ to red-eared slider turtles are presented in Fig. 1 and Table 1, respectively. Danofloxacin was detected in all turtles up to $144 \mathrm{hr}$ following IV and IM administration. Following IV administration, $\mathrm{C}_{0}$ was $10.57 \mu \mathrm{g} / \mathrm{ml}$ at $0.5 \mathrm{hr}$ and $\mathrm{C}_{\max }$, which was reached with $\mathrm{T}_{\max }$ of $1.5 \mathrm{hr}$ following IM administration, was $8.75 \mu \mathrm{g} / \mathrm{ml}$. Danofloxacin exhibited higher AUC and longer $\mathrm{t}_{1 / 2 \kappa \mathrm{z}}$ and $\mathrm{MRT}_{0-\infty}$ after IM administration than after IV administration. Following IV administration, $\mathrm{V}_{\mathrm{dss}}$ and $\mathrm{Cl}_{\mathrm{T}}$ were $1.29 \mathrm{l} / \mathrm{kg}$ and 0.04 $l / \mathrm{hr} / \mathrm{kg}$, respectively. The bioavailability after IM administration was $139.89 \%$.

\section{DISCUSSION}

There were no local or systemic side effects in turtles following IV and IM administration of danofloxacin at the dose of $6 \mathrm{mg} / \mathrm{kg}$.

Table 1. Mean \pm SD plasma pharmacokinetic parameters of danofloxacin following intravenous (IV) and intramuscular (IM) administrations at the dose of $6 \mathrm{mg} / \mathrm{kg}$ in red-eared slider turtles $(\mathrm{n}=8)$

\begin{tabular}{lcc}
\hline \multicolumn{1}{c}{ Parameter } & IV & IM \\
\hline $\mathrm{t}_{1 / 2 \AA z}(\mathrm{hr}) \mathrm{HM}$ & $24.17 \pm 1.21$ & $32.00 \pm 1.50$ a) \\
$\mathrm{AUC}_{0-24}(\mathrm{hr} . \mu \mathrm{g} / \mathrm{m} l)$ & $86.10 \pm 7.59$ & $98.27 \pm 8.89^{\mathrm{a})}$ \\
$\mathrm{AUC}_{0-144}(\mathrm{hr} . \mu \mathrm{g} / \mathrm{m} l)$ & $140.75 \pm 13.30$ & $190.03 \pm 23.41^{\mathrm{a})}$ \\
$\mathrm{AUC}_{0-\infty}(\mathrm{hr} . \mu \mathrm{g} / \mathrm{m} l)$ & $143.31 \pm 13.80$ & $198.23 \pm 25.41^{\mathrm{a})}$ \\
$\mathrm{MRT}_{0-\infty}(\mathrm{hr}) \mathrm{HM}$ & $30.64 \pm 1.58$ & $41.15 \pm 2.26^{\mathrm{a})}$ \\
$\mathrm{MAT} \mathrm{hr})$ & - & $10.50 \pm 2.94$ \\
$\mathrm{Cl}_{\mathrm{T}}(l / \mathrm{hr} / \mathrm{kg})$ & $0.04 \pm 0.00$ & - \\
$\mathrm{V}_{\mathrm{dss}}(l / \mathrm{kg})$ & $1.29 \pm 0.11$ & - \\
$\mathrm{T}_{\max }(\mathrm{hr}) \mathrm{M}$ & - & 1.5 \\
$\mathrm{C}_{\max }(\mu \mathrm{g} / \mathrm{m} l)$ & - & $8.75 \pm 0.72$ \\
$\mathrm{C}_{0}(\mu \mathrm{g} / \mathrm{m} l)$ & $10.57 \pm 0.75$ & - \\
$\mathrm{F} \%$ & - & $139.89 \pm 25.16$ \\
\hline
\end{tabular}

a) Statistically different from IV administration $(P<0.05)$. $\mathrm{t}_{1 / 2 \mathrm{Z}}$, terminal elimination half-life; AUC, area under the plasma concentration-versus time curve; MRT, mean residence time; MAT, mean absorption time; $\mathrm{Cl}_{\mathrm{T}}$, total clearance; $\mathrm{V}_{\mathrm{dss}}$, volume of distribution at steady state; $\mathrm{T}_{\max }$, time to reach the peak concentration; $\mathrm{C}_{\max }$, peak concentration; $\mathrm{C}_{0}$, initial concentration; $\mathrm{F}$, absolute bioavailability; $\mathrm{HM}$, harmonic mean; M, median. 
No side effects were reported following IV, IM, subcutaneous (SC), and oral administration of danofloxacin at the dose of 6-15 $\mathrm{mg} / \mathrm{kg}$ to C. caretta [19], tilapia [8], sea bass [29], and crucian carp [27].

The mean $\mathrm{t}_{1 / 2 \mathrm{Kz}}(24.17 \mathrm{hr})$ obtained after the IV administration of danofloxacin to red-eared slider turtles was longer than that reported in C. caretta (15.4 hr) [19] and consistent with previously reported value in Amur sturgeon (22.19 hr) [18]. Because $\mathrm{t}_{1 / 2 \lambda z}$ is a hybrid parameter, it is difficult to evaluate the differences in the elimination half-life between species [28]. The different $t_{1 / 2 \lambda z}$ in the interspecies can be related to the differences in the elimination or distribution processes. In red-eared slider turtles, mean $\mathrm{Cl}_{\mathrm{T}}(0.04 \mathrm{l} / \mathrm{hr} / \mathrm{kg})$ and $\mathrm{V}_{\mathrm{dss}}(1.29 \mathrm{l} / \mathrm{kg})$ were lower $(0.11 \mathrm{l} / \mathrm{hr} / \mathrm{kg})$ and partially similar $(1.02 \mathrm{l} / \mathrm{kg})$ to previously reported values in $C$. caretta, respectively [19]. Danofloxacin has large $\mathrm{V}_{\mathrm{dss}}$ owing to its lipophilic structure and low binding activity to plasma proteins [12]. Although plasma protein binding activity of danofloxacin is unknown for reptiles, it ranges from $17 \%$ to $49 \%$ in other animals $[10,12]$. The larger $\mathrm{V}_{\mathrm{dss}}$ value in this study than that observed in C. caretta may be related to the difference in the binding activity of danofloxacin to plasma protein. Danofloxacin is metabolized into N-desmethyldanofloxacin, N-oxide, and glucuronide-conjugate metabolites, and this metabolism differs among species [2]. In this study, lower $\mathrm{Cl}_{\mathrm{T}}$ than that observed with $C$. caretta may be related to the species difference in the metabolism and excretion of danofloxacin.

The $\mathrm{t}_{1 / 2 \mathrm{~K} z}$ and $\mathrm{MRT}_{0-\infty}$ following IM administration of danofloxacin were longer than those following IV administration. Turtles are ectotherm animals that can adapt to lower temperatures, and they can regulate their physiological and biochemical functions based on the temperature. Therefore, cardiac output and tissue perfusion depend on ambient temperatures [16]. In this study, maintaining turtles at $22-24^{\circ} \mathrm{C}$ ambient temperature may have reduced cardiac output and tissue perfusion. Reduced tissue perfusion may have led to the restriction of elimination by causing slow absorption of danofloxacin. In addition, the long $\mathrm{t}_{1 / 2 \mathrm{Kz}}$ of danofloxacin after extravascular administration may be caused by biphasic absorption process or flip-flop kinetics. However, MAT values obtained during the study do not support the flip-flop kinetics. Biphasic absorption process or flip-flop kinetics following the extravascular administration of danofloxacin has been reported in some species [9, 17].

The mean $\mathrm{AUC}_{0-\infty}$ following IM administration of danofloxacin was higher than that following IV administration. Following IV administration, $\mathrm{C}_{0}(0.5 \mathrm{hr})$ was $10.57 \mu \mathrm{g} / \mathrm{ml}$, and $\mathrm{C}_{\max }$, reached with $1.5 \mathrm{hr} \mathrm{T}_{\max }$, following IM administration was $8.75 \mu \mathrm{g} /$ $\mathrm{ml}$. Danofloxacin was detected up to $144 \mathrm{hr}$ following administration via both routes. Plasma concentration at the time of last sampling for IV and IM administrations were 0.07 and $0.18 \mu \mathrm{g} / \mathrm{m} l$, respectively. In this study, $\mathrm{C}_{\max }$ and $\mathrm{T}_{\max }$ obtained following IM administration were lower $(10.25 \mu \mathrm{g} / \mathrm{m} l)$ and longer $(1.2 \mathrm{hr})$ than previously reported values in C. caretta, respectively [19]. The mean bioavailability following IM administration in red-eared slider turtles was $139.89 \%$. This was higher than what was previously reported for C. caretta (104.81\%) [19]. In this study, high bioavailability of danofloxacin following IM administration may be caused by extended $t_{1 / 2 \AA z}$ and increased AUC owing to the slow absorption rate related with the biphasic absorption process.

In veterinary medicine, danofloxacin is recommended for use at the dose of $1.25-15 \mathrm{mg} / \mathrm{kg}[1,27]$. Because $6 \mathrm{mg} / \mathrm{kg}$ of danofloxacin was reported to be effective against various infections in C. caretta [19], this dose level was selected for this study. Serial blood samples were collected from dorsal cervical sinus (left and right) instead of the jugular vein because of the small sizes of red-eared slider turtles. However in turtles, vessels except for jugular vein are contaminated with lymphatic fluid. $\mathrm{C}_{\text {max }}(8.75$ $\mu \mathrm{g} / \mathrm{m} l$ ) value of danofloxacin obtained in red-eared slider turtles following IM administration at $6 \mathrm{mg} / \mathrm{kg}$ dose was lower than that reported in $C$. caretta $(10.25 \mu \mathrm{g} / \mathrm{m} l)$ [19] and higher than that reported in rabbits $(1.87 \mu \mathrm{g} / \mathrm{m} l)$ [9]. In turtles, higher plasma $\mathrm{C}_{\text {max }}$ level in turtles than in other animal species may be due to the lymphatic fluid being mixed into the plasma.

In conclusion, danofloxacin has clinically superior pharmacokinetic properties including the complete IM bioavailability, slow elimination and wide volume of distribution in red-eared slider turtles. Further pharmakinetics/pharmacodynamics studies are necessary for the treatment of diseases caused by susceptible bacteria with known MIC values in red-eared slider turtles.

ACKNOWLEDGMENT. This study was presented as an abstract at the International Health Sciences Conference (IHSC) Diyarbakir, Turkey, 14-17 November, 2018.

\section{REFERENCES}

1. Aliabadi, F. and Lees, P. 2003. Pharmacokinetic-pharmacodynamic integration of danofloxacin in the calf. Res. Vet. Sci. 74: 247-259. [Medline] [CrossRef]

2. Anonymous. 2018. http://www.fao.org/docrep/W8338E/w8338e07.htm [accessed on July 15, 2018$].$

3. Ariel, E. 2011. Viruses in reptiles. Vet. Res. (Faisalabad) 42: 100. [Medline] [CrossRef]

4. Bosch, S., Tauxe, R. V. and Behravesh, C. B. 2016. Turtle-Associated Salmonellosis, United States, 2006-2014. Emerg. Infect. Dis. 22: 1149-1155. [Medline]

5. Burger, J. 2009. Red-eared slider turtles (Trachemys scripta elegans). http://depts.washington.edu/oldenlab/wordpress/wp-content/uploads/2013/03/ Trachemys-scripta elegans_Burger.pdf [accessed on June 15, 2018].

6. Chitty, J. and Raftery, A. 2013. Essentials of Tortoise Medicine and Surgery, Wiley Blackwell, West Sussex.

7. CVMP 2002. Danofloxacin (extension to all food producing species) summary report (6). European Agency for the Evaluation of Medicinal Products. EMEA/MRL/818/02-FINAL. https:/www.ema.europa.eu/en/documents/mrl-report/danofloxacin-extension-all-food-producing-speciessummary-report-6-committee-veterinary-medicinal_en.pdf [accessed on July 25, 2018].

8. Fan, Y. C., Sheu, S. Y., Lai, H. T., Chang, M. H., Chen, P. H., Lei, Y. C., Kuo, T. F. and Wang, C. Y. 2015. Residue depletion study of danofloxacin in cultured tilapia (Oreochromis mossambicus). J. AOAC Int. 98: 575-579. [Medline] [CrossRef]

9. Fernández-Varón, E., Marin, P., Escudero, E., Vancraeynest, D. and Cárceles, C. M. 2007. Pharmacokinetic-pharmacodynamic integration of danofloxacin after intravenous, intramuscular and subcutaneous administration to rabbits. J. Vet. Pharmacol. Ther. 30: 18-24. [Medline] [CrossRef] 
10. Friis, C. 1993. Penetration of danofloxacin into the respiratory tract tissues and secretions in calves. Am. J. Vet. Res. 54: 1122-1127. [Medline]

11. Gibbons, G. M. 2014. Advances in reptile clinical therapeutics. J. Exot. Pet Med. 23: 21-38. [CrossRef]

12. Goudah, A. and Mouneir, S. M. 2009. Disposition kinetics and tissue residues of danofloxacin in Muscovy ducks. Br. Poult. Sci. 50: 613-619. [Medline] [CrossRef]

13. Isler, C. T., Altug, M. E., Secer, F. S. and Cantekin, Z. 2015. Treatment of bath with enrofloxacin in red-eared sliders (Trachemys scripta elegans) suffer from conjunctivitis and its results. Kafkas Univ. Vet. Fak. Derg. 21: 429-431.

14. Jacobson, E. R., Brown, M. B., Wendland, L. D., Brown, D. R., Klein, P. A., Christopher, M. M. and Berry, K. H. 2014. Mycoplasmosis and upper respiratory tract disease of tortoises: a review and update. Vet. J. 201: 257-264. [Medline] [CrossRef]

15. Janecko, N., Pokludova, L., Blahova, J., Svobodova, Z. and Literak, I. 2016. Implications of fluoroquinolone contamination for the aquatic environment-A review. Environ. Toxicol. Chem. 35: 2647-2656. [Medline] [CrossRef]

16. Kik, M. J. L. and Mitchell, M. A. 2005. Reptile cardiology: a review of anatomy and physiology, diagnostic approaches, and clinical disease. $J$. Exot. Pet Med. 14: 52-60.

17. Lopez, B. S., Giguère, S., Berghaus, L. J., Mullins, M. A. and Davis, J. L. 2015. Pharmacokinetics of danofloxacin and N-desmethyldanofloxacin in adult horses and their concentration in synovial fluid. J. Vet. Pharmacol. Ther. 38: 123-129. [Medline] [CrossRef]

18. Lu, T. Y. 2004. The assessment of danofoxacin used against Amur sturgeon infected by Aeromonas hydrophila, PhD thesis, Northeast Agricultural University, HarBin.

19. Marín, P., Bayón, A., Fernández-Varón, E., Escudero, E., Clavel, C., Almela, R. and Cárceles, C. M. 2008. Pharmacokinetics of danofloxacin after single dose intravenous, intramuscular and subcutaneous administration to loggerhead turtles Caretta caretta. Dis. Aquat. Organ. 82: 231-236. [Medline] [CrossRef]

20. Nakamura, S. 1995. Veterinary use of new quinolones in Japan. Drugs 49 Suppl 2: 152-158. [Medline] [CrossRef]

21. Norton, T. M. 2005. Chelonian emergency and critical care. J. Exot. Pet Med. 14: 106-130.

22. O'Keeffe, M. S. 2006. Red-eared slider turtles in Australia and New Zealand. Brisbane, Queensland 3-7 April, 2006. https://www.pestsmart.org.au/ wp-content/uploads/2010/11/REST_Workshop_April2006.pdf [accessed on June 25, 2018].

23. Potter, T., Illambas, J., Pelligand, L., Rycroft, A. and Lees, P. 2013. Pharmacokinetic and pharmacodynamic integration and modelling of marbofloxacin in calves for Mannheimia haemolytica and Pasteurella multocida. Vet. J. 195: 53-58. [Medline] [CrossRef]

24. Rataj, A. V., Lindtner-Knific, R., Vlahović, K., Mavri, U. and Dovč, A. 2011. Parasites in pet reptiles. Acta Vet. Scand. 53: 33. [Medline] [CrossRef]

25. Real, R., Egido, E., Pérez, M., González-Lobato, L., Barrera, B., Prieto, J. G., Alvarez, A. I. and Merino, G. 2011. Involvement of breast cancer resistance protein (BCRP/ABCG2) in the secretion of danofloxacin into milk: interaction with ivermectin. J. Vet. Pharmacol. Ther. 34: 313-321. [Medline] [CrossRef]

26. Summa, N. M. and Guzman, D. S. 2017. Evidence-based advances in avian medicine. Vet. Clin. North Am. Exot. Anim. Pract. 20 : $817-837$. [Medline] [CrossRef]

27. Tan, C. 2008. Pharmacokinetics and residues studies of danofloxacin mesylate in crucian carps (Carassius auratus Linnaeus), Phd thesis, Hunan Agricultural University, Hunan.

28. Toutain, P. L. and Bousquet-Mélou, A. 2004. Bioavailability and its assessment. J. Vet. Pharmacol. Ther. 27: 455-466. [Medline] [CrossRef]

29. Vardali, S. C., Kotzamanis, Y. P., Tyrpenou, A. E. and Samanidou, V. F. 2017. Danofloxacin depletion from muscle plus skin tissue of European sea bass (Dicentrarchus labrax) fed danofloxacin mesylate medicated feed in seawater at $16^{\circ} \mathrm{C}$ and $27^{\circ} \mathrm{C}$. Aquaculture 479: $538-543$. [CrossRef]

30. Walker, R. D. 2000. The use of fluoroquinolones for companion animal antimicrobial therapy. Aust. Vet. J. 78: 84-90. [Medline] [CrossRef] 